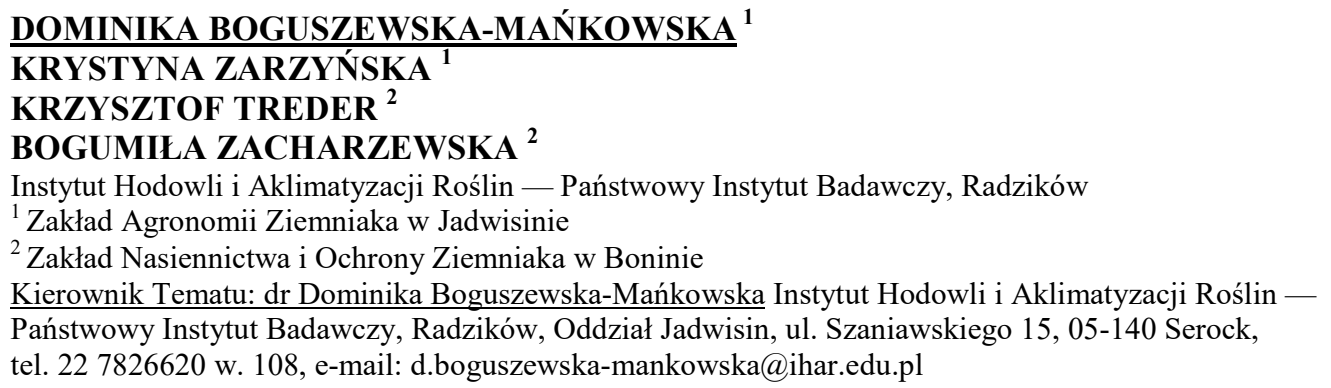

Prace zostały wykonane $w$ ramach badań podstawowych na rzecz postępu biologicznego w produkcji roślinnej na podstawie decyzji Ministra Rolnictwa i Rozwoju Wsi nr HOR.hn.802.19.2018, Zadanie 59.

\title{
Badania tolerancji odmian ziemniaka na stresy abiotyczne w świetle postępujących zmian klimatycznych
}

\section{Drought tolerance of potato cultivars to abiotic stress in relation to climate change}

Słowa kluczowe: odmiana, susza glebowa, wysoka temperatura, ziemniak

Badania Mittlera i in. (2006) wykazały, że straty w produkcji rolniczej USA spowodowane suszą wyniosły około 20 bilionów USD w latach 1980-2004, natomiast łącznym wystąpieniem suszy i wysokiej temperatury aż 120 bilionów USD. Obecnie stosowane techniki dotyczą atestacji roślin odpornych na działanie pojedynczego niekorzystnego czynnika środowiska. Dlatego, istnieje pilna konieczność podjęcia badań nad reakcją roślin na łączne działanie więcej niż jednego czynnika środowiska modyfikującego wzrost i rozwój roślin, a tym samym wielkość i jakość plonu rolniczego. Ponadto $\mathrm{w}$ celu aplikacji wyników w/w badań, zasadne jest podjęcie próby identyfikacji takich enzymów, których aktywność pod wpływem stresu zmienia się w znaczącym stopniu i różnicuje odmiany odporne i podatne na niedobory wody. Ten sposób podejścia powinien pozwolić na opracowanie mikropłytkowych metod oznaczania aktywności, umożliwiających szybką ocenę odporności odmian na stresy. 
Dużą rolę w odporności roślin na suszę glebową odgrywa system korzeniowy. Próby znalezienia korelacji między wielkością systemu korzeniowego a wielkością plonu podejmowane były przez wielu badaczy, nie wszystkim jednak udawało się uzyskać proste zależności (Leszczynski i Tanner, 1976; Opena i Porter, 1999; Aspray i in., 1983; Parker i in., 1989; Stalham i Allen, 2001; Vos i Groenvald, 1986; Zarzyńska i in., 2017). W pracy przeglądowej dotyczącej badań nad systemem korzeniowym ziemniaka Iwama (2008) stwierdza wprawdzie, że masa korzeni generalnie wskazuje pozytywne korelacje z plonem bulw. Rozpoznanie i określenie wielkości i zasięgu systemu korzeniowego u różnych odmian daje możliwość skierowania w rejony o częstszych niedoborach opadów odmian, które warunki takie mogą znosić łatwiej, a więc z mniejszym uszczerbkiem dla plonu. Informacje o wielkości systemu korzeniowego mogą stanowić dobrą wskazówkę dla hodowców.

Celem podjętych badań było wytypowanie odmian o różnej wrażliwości na suszę glebową, wysoką temperaturę, poznanie zależności pomiędzy tolerancyjnością ziemniaka na suszę glebową i wysoką temperaturę a budową morfologiczną i architekturą systemu korzeniowego, opracowanie metod szybkiego wykrywania enzymów odpowiedzialnych za tolerancyjność ziemniaka na suszę glebową.

Nasze wyniki wskazują, że oba stresy tj. suszy glebowej i wysokiej temperatury powodowały zmiany w morfologii roślin. Susza miała większy wpływ niż stres wysokiej temperatury. Największe zmiany zachodziły jednak przy obu stresach występujących jednocześnie. Wykazano również różnice odmianowe. Na podstawie naszych wyników można wybrać odmiany o małych zmianach morfologicznych pod wpływem stosowanych stresów jak Lech, Laskara i odmiany o dużych zmianach: Lawenda i Jurata.

$\mathrm{Na}$ podstawie dotychczas prowadzonych badań zaobserwowano, że zarysowuje się zależność pomiędzy wielkością systemu korzeniowego a wielkością masy nadziemnej rośliny i plonem bulw. Jak wykazano, odmiany ziemniaka różnią się zarówno wielkością całej masy korzeniowej, jak i dystrybucją korzeni w poszczególnych warstwach gleby. W naszych badaniach nie stwierdzono istotnych zależności między wielkością systemu korzeniowego a plonem bulw pochodzącym z kombinacji gdzie nie stosowano suszy glebowej, większą korelację zanotowano z plonem bulw z kombinacji, w której zastosowano suszę glebową, a jeszcze większą ze spadkiem plonu między kombinacją kontrolną i z zastosowaną suszą. Była to oczywiście zależność odwrotna tj. im większy system korzeniowy tym mniejszy spadek plonu. Wykazano, również że im większy udział masy korzeni w całej biomasie rośliny i im niższy stosunek części nadziemnej do podziemnej tym wyższa tolerancja odmiany na niedobór wody.

Badania biochemiczne sześciu odmian ziemniaka o rożnej tolerancyjności na suszę wykazały, że najwyższy wzrost stężenia L-proliny pod wpływem stresu suszy w wysokiej temperaturze $\left(38^{\circ} \mathrm{C}\right)$ zaobserwowano dla odmiany Bogatka. Koncentracja L-proliny dla tej odmiany wzrosła sześciokrotnie w piątym dniu suszy w $38^{\circ} \mathrm{C}$. Przy optymalnych warunkach temperaturowych $21^{\circ} \mathrm{C}$ nie zaobserwowano znaczącego podwyższenia stężenia L-proliny zarówno w przypadku kontroli, jak i suszy. Zauważono niewielki wzrost stężenia L-proliny $u$ roślin poddanych stresowi suszy i temperatury $38^{\circ} \mathrm{C}$ w przypadku odmian Gawin i Cekin. W pozostałych odmianach ziemniaka zarówno 
susza, jak i wysoka temperatura nie indukowały wyraźnego wzrostu stężenia L-proliny w badanym okresie pięciu dni. W przypadku odmian Gwiazda i Oberon, poziom L-proliny był taki sam w ciągu pięciu dni dla wszystkich badanych kombinacji, co świadczy, że w badanym okresie odmiany te nie reagowały wzmożoną produkcją tego aminokwasu w odpowiedzi na zadany stres.

\section{LITERATURA}

Iwama K. 2008. Physiology of the potato: New insights into root system and repercussions for crop management. Potato Research, 51:333 - 353.

Leszczynski, D. B., Tanner C.B. 1976. Seasonal variation of root distribution of irrigated, field-grown Russet Burbank potato. Am. Potato J. $69-78$.

Mittler R. 2006. Abiotic stress, the field environment and stress combination. Trends in Plant Science 11: 15 $-19$.

Opena G. B., Porter G. A. 1999. Soil management and supplemental irrigation effects on potato: II. Root growth. Agronomy Journal 91: $426-431$.

Parker, C. J., Carr M. K. V, Jarris N. J, Evans M. T. B., Lee V. H. 1989. Effect of subsoil loosening and irrigation on soil physical properties, root distribution and water uptake of potatoes (Solanum tuberosum). Soil Tillage Res. 13: $267-285$.

Stalham M. A., Allen E. J. 2001. Effect of variety, irrigation regime and planting date on depth, rate, duration and density of root growth in the potato (Solanum tuberosum) crop. Journal of Agricultural Science 137: $251-270$.

Vos J., Groenwold J. 1986. Root growth of potato crops on a marine clay soil. Plant and Soil: 161 : 289 298.

Zarzyńska K., Boguszewska- Mańkowska D., Nosalewicz A. 2017. Differences in size and architecture of the potato cultivars root system and their tolerance to drought stress. Plant Soil and Envin. 63: 159 — 164. 
